ex Instituto Archaeologico Universitatis de Rolando Eötvös nominatae

C

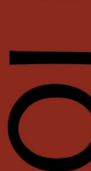

ப

$\varangle$

工

$\cup$

ه

$<$

in

ㄴ
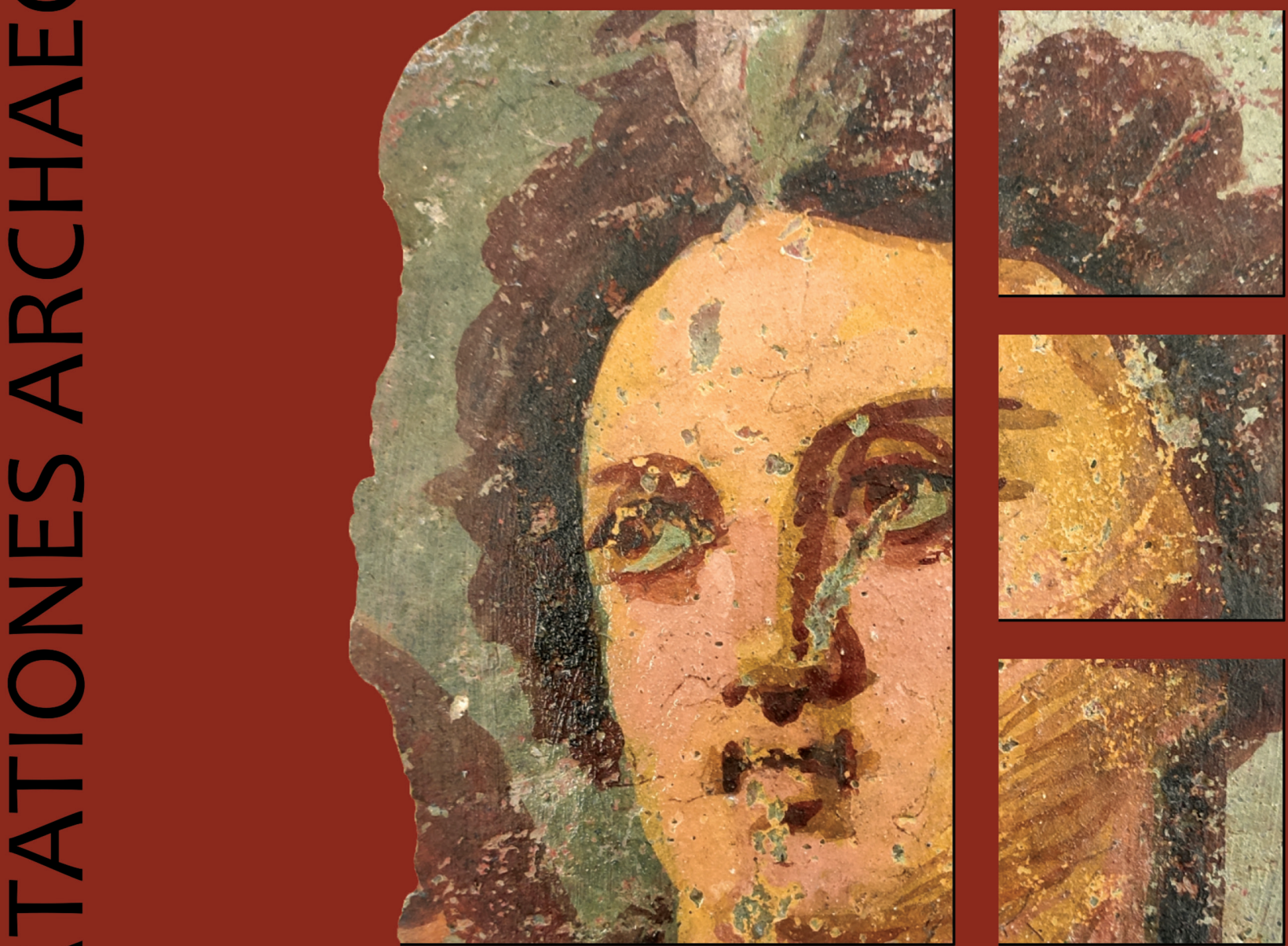

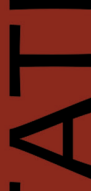

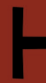

ח

Ш

un

n

0
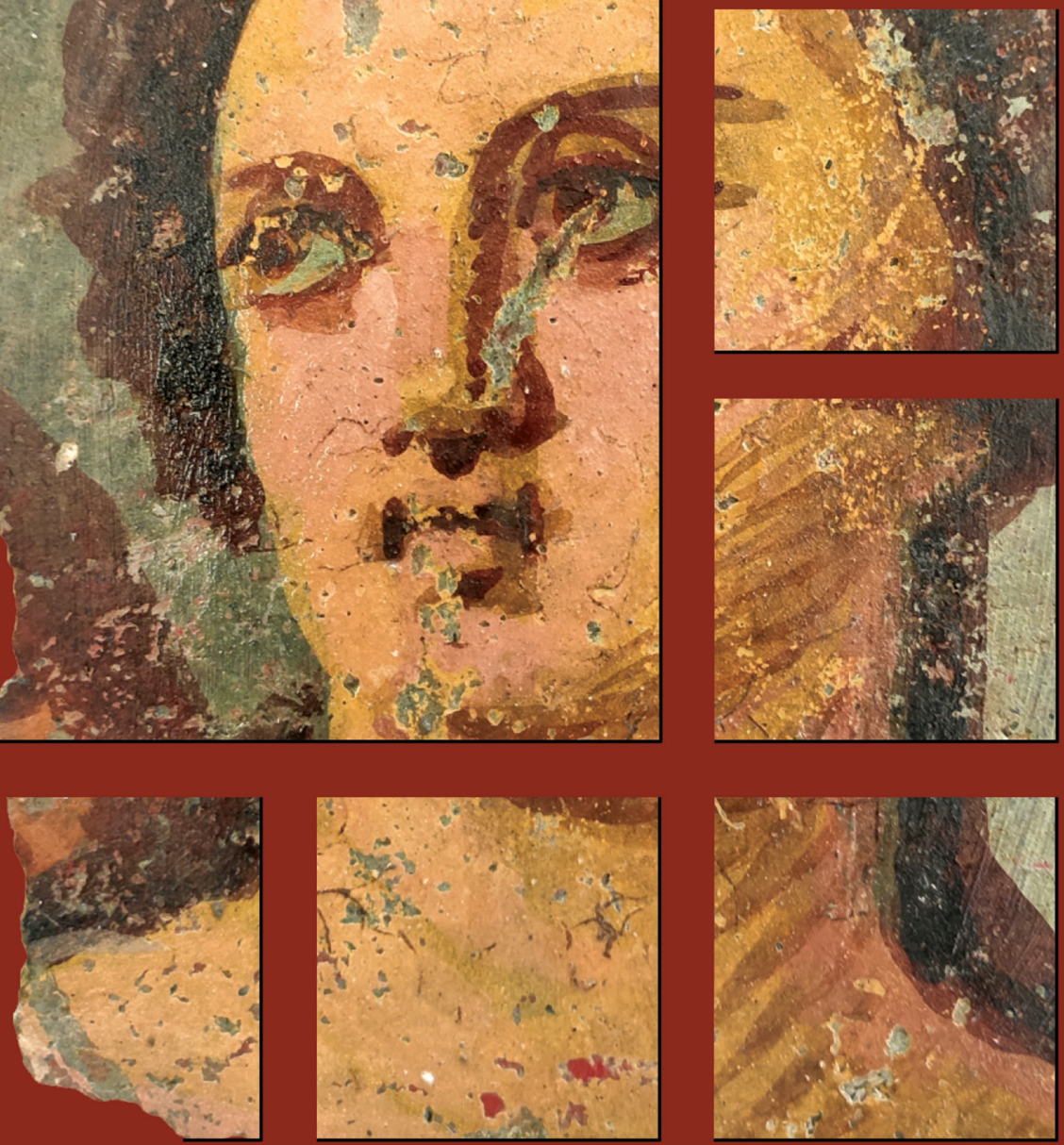

Serp 30 No. 8. 2020 


\section{Dissertationes Archaeologicae ex Instituto Archaeologico}

Universitatis de Rolando Eötvös nominatae Ser. 3. No. 8.

Budapest 2020 
Dissertationes Archaeologicae ex Instituto Archaeologico Universitatis de Rolando Eötvös nominatae Ser. 3. No. 8.

Editor-in-chief:

DÁvid Bartus

Editorial board:

LÁsZló BARTOSIEWICZ

LÁsZLÓ BORHY

ZOLTÁN CZAJLIK

IsTVÁN FELD

GÁBOR KALLA

PÁL RACZKY

MiKLÓS SZABÓ

Tivadar Vida

Technical editor:

Gábor VÁczi

Proofreading:

Szilvia BARTUS-SzÖLLŐsI

Zsófia KondÉ

Márton SZILÁGYI

Aviable online at http://ojs.elte.hu/dissarch

Contact: dissarch@btk.elte.hu

ISSN 2064-4574

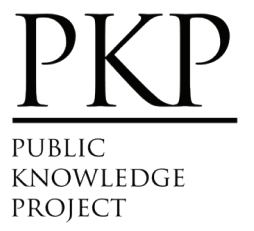

๑ ELTE Eötvös Loránd University, Institute of Archaeological Sciences

Layout and cover design: Gábor Váczi

Budapest 2020 


\section{CONTENTS}

\section{ARTICLES}

Maciej WAWRZCZAK - Zuzana KASENČÁKovÁ

Stará L'ubovña - Lesopark. Late Palaeolithic site and the problems associated with raw material mining

Attila PÉNTEK - Norbert FARAgó

Chipped stone assemblages from Schleswig-Holstein (North Germany) in the collection of the Institute of Archaeological Sciences - ELTE Eötvös Loránd University

Bence Soós 49

Middle Iron Age Cemetery from Alsónyék, Hungary

Tamás Szeniczey - Tamás Hajdu 107

Appendix - Results of the analysis of the Early Iron Age human remains unearthed at Alsónyék, Hungary

Lajos JuHÁsz - József Géza Kiss

Bound in bronze - a Roman bronze statuette of a barbarian prisoner

Csilla SÁRó

The fibula production of Brigetio: clay moulds

\section{Field Reports}

András Füzesi - Knut Rassmann - Eszter BÁnffy - Hajo Hoehler-Brockmann -

Gábor Kalla - Nóra Szabó - Márton SzIlágyi - Pál Raczky

Test excavation of the "pseudo-ditch" system of the Late Neolithic settlement complex at Öcsöd-Kováshalom on the Great Hungarian Plain

Gábor VÁczi - László RupNIK - Zoltán CZAJLIK - Gábor MEsterházy Bettina BitTner - Kristóf FÜlöP - Denisa M. LÖNHARdT - Nóra Szabó

The results of a non-destructive site exploration and a rescue excavation at the site of Pusztaszabolcs-Dohányos völgy északi part

Dávid BArtus - László Borhy - Szilvia JohÁczi - Emese SzÁmadó 181

Excavations in the legionary fortress of Brigetio in 2019 
Dávid BArtus - László Borhy - Emese SzÁmadó - Lajos Juhász - Bence Simon -

Ferenc Barna - Anita Benes - Szilvia Joháczi - Rita Olasz - Melinda Szabó

Excavations in Brigetio in 2020

\section{Thesis Abstracts}

Anett OszTÁs

The settlement history of Alsónyék-Bátaszék.

Complex analysis of its buildings in the context of the Lengyel culture

Csilla SzÁRAz

The region of the Zala and Mura Rivers (Zala County) in the Late Bronze Age.

Late Tumulus and Urnfield period

Ágnes KIRÁly

Human remains unearthed in settlement context from the Late Bronze Age -

Early Iron Age (Reinecke BD-HaB3) Northeastern Hungary

Gergely BóKA

Transformation of settlement history in the Körös Region in the period between the Late Bronze Age and the end of Iron Age

Gabriella G. DeLbó

Pottery production of the settlement complex of Brigetio

Adrienn Katalin BLAY

Die Beziehungen zwischen dem Karpatenbecken und dem Mediterraneum

von der II. Hälfte des 6. bis zum 8. Jahrhundert n. Chr. anhand Schmuckstücken

und Kleidungszubehör

Levente SAMU

293

Die mediterranen Kontakte des Karpatenbeckens in der Früh- und Mittel-

awarenzeit im Licht der Männerkleidung. Gürtelschnallen und Gürtelgarnituren

\section{REviEWS}

Gábor MESTERHÁZY

Czajlik, Z. - Črešnar, M. - Doneus, M. - Fera, M. - Hellmith Kramberger, A. Mele, M. (eds): Researching Archaelogical Landscapes Across Borders - Strategies,

Methods and Decisions for the 21th Century. Graz-Budapest, 2019. 


\title{
The region of the Zala and Mura Rivers (Zala County) in the Late Bronze Age
}

\author{
Late Tumulus and Urnfield period
}

Csilla SzÁRAZ

Thúry György Museum

Nagykanizsa

szcsilla.muzeum@gmail.com

\begin{abstract}
Abstract of PhD thesis submitted in 2020 to the Archaeology Doctoral Programme, Doctoral School of History, Eötvös Loránd University, Budapest under the supervision of Gábor V. Szabó.
\end{abstract}

\section{The objectives of the dissertation}

The dissertation has the objective to evaluate the archaeological sites located in the region between the Zala River and the Mura River (Zala County) as well as to process their archaeological material. The paper focuses on the period between BD and HaB2 along the chronological framework established by P. Reinecke and H. Müller-Karpe. The dissertation is an informative source statement and it aims to present the settlement history characteristics, burial practices and sacrificial deposit features concerning the examined area and the chosen period. This is a basic research that aims to approach the presentation of the regional characteristics from the specific by means of the method of inductive reasoning.

Since the comprehensive work of E. Patek and F. Kőszegi only partial publications have been issued about the history of Zala County in the Late Bronze Age. However, in the last decades during the preventive excavations, which were related to big investments and covered large surface areas, several significant settlements and cemetery parts were brought to light. Apart form the Bronze Age settlement and cemetery parts revealed due to the construction of the M7-M70 motorways (e.g. Tornyiszentmiklós-Nagyszegi dűlő, Muraszemenye-Aligvári mező, Galambok-Hársas erdő, Zalakomár-Alsó csalit, Nagyrécse-Baráka) there were significant archaeological works in progress at several fortified settlements: representative archaeological material was unearthed during the excavation of Zalaszentiván-Kisfaludi-hegy and VárvölgyNagyláz-hegy. Major archaeological material is known from the settlement surrounded by a ditch at Balatonmagyaród-Hídvégpuszta, too.

Zala County delimited by the Zala and Mura Rivers is an artificial geographical unit nowadays but from the aspect of the dissertation it is a well defined sample area the examination of which provides an opportunity to summarise the characteristics of the wider cultural geographical regions by means of a systematic overview of the connections between the unearthed archaeological material, the settlement parts and burials. Due to its topography Zala County is the intersection area of different types of territories so it has a transitory nature and is not separated from the neighbouring landscapes along well-defined borders. When the archaeological sites and their archaeological materials are examined, this transitory nature is 
characteristic. The surface of Göcsej and Örség covered with forests is one of the areas that determine the archaeological physiognomy. It seems to be the case that this countryside was typically closed in this period (as well as in other archaeological periods). Hardly any archaeological sites are known fron this area. The archaeological sites located near the Keszthely Hills, the Keszthely Basin and Lake Balaton also have connections towards north, north-west and north-east and the number of the known settlements is high, too. This area may be best characterised by openness. The archaeological sites of the Zala Valley have connections towards north and north-west but they have strong links to the archaeological material of the Slovenian and Croation areas. The settlements along the Mura River may also be related to the Slovenian and Croatian areas.

The dissertation aims to provide a comprehensive picture of the particular era by means of introducing and evaluating archaeological sites and materials that have not been published or have been published only in prior communication. The guideline of the processing comprises the classic archaeological monographies and catalogue studies. After collecting all the known archaeological sites and reviewing their material the dissertation focuses on 19 sites out of which 11 were the location of preventive excavation. In the first stage the paper summarises the results of basic research concerning each archaeological site then based on this establishes the unique characteristics related to the area and the period as well as those in the case of which a parallel can be found with other areas of the period regarding settlements, burials, sacrificial deposits and economy.

The introduction of the 19 archaeologial sites starts with the topographic location of the certain sites (topographic map, satellite map, Joseph II-type of military map section) and then the introduction of the cumulative ground plan has a predominant role when the objects belonging to the period are highlighted separately, too. The short summary of the research history of each archaeological site is followed by the description of the objects and the introduction of the site's finds by means of informative tables and tipological figures.

After the presentation of the archaeological sites the dissertation elaborates on the characteristics of settlements, burials and sacrificial deposits by focusing on the separation of the certain chronological horizons and the presentation of the relationship networks belonging to the cultural imprint of the different periods inside the archaeological material of the region. The dissertation pays special attention to the presentation of the examined area and to its particular elements, too.

The fact that the summary of the new findings of the neighbouring Slovenian and Croatian areas, which can be related to new preventive excavations, have been published in several publications and monographies supported by radiocarbon data also justifies the idea that the excavations carried out on large surfaces in the area of Zala County should be processed and assessed. Furthermore, the extent to which the sites belonging to the period in Veszprém, Vas and partially in Somogy Counties are processed is far bigger than that of the material in Zala County. The area of Zala County is an unexplored territory in the research compared to the Slovenian region as well as the northern and north-eastern sites of the Transdanubia.

As for processing the archaeological sources the paper aims to present the particular sites in equal details as far as possible so that they can be compared to each other possibly to the same extent. The goal of the work is the illustrative introduction of a particular area and period as 
well as the publication of a scientific work and informative source statement that can be used well later on for the examination of the region's finds by the researchers of the period. Hopefully, the finds shown mainly with photos and profile drawings will help the work of those who intend to process the similar assemblages of the south-west Transdanubia in the future.

The archaeological finds from Zala County serving as the base for the results of the dissertation contributes to the detailed demonsatration of the Reinecke $\mathrm{BD}, \mathrm{HaA}$ and $\mathrm{HaB}$ periods. The transitory periods of the three ages (late tumulus and urnfield period) and the end of the urnfield period has been a question in the professional literature for a long time. The examined archaeological sites and their definitive materials form a chronological arch. The papers aim was to specify and refine this arch. The heyday of the Muraszemenye-Aligvári-mező site was in the transitory period of the Reinecke BD and the HaA1 eras. The site in Zalaszentiván-Kisfaludi-hegy was inhabited from the Koszider period until the Celtic Age, which is confirmed by the observations of the preventive excavation. The ceramic and metal finds of the Várvölgy-Nagyláz-hegy can be dated back to the later urnfield period. So the examination of the transitory period of the BD-HaA1 era and the analysis of the $\mathrm{HaA} 2-\mathrm{HaB} 1$ period have a dominant position among the findings of the dissertation.

In addition to studying chronological questions and relationship networks the paper examines the role of the settlements at high altitudes in the landscape and makes an attempt to separate the theoretical spheres of influence and to answer certain questions reflecting on territorial and social hierarchy.

\section{Sources of the dissertation}

The basic sources of the paper can be found in the institutes of the museum network that divides Zala County into three parts according to collection areas. The examined archaeological material can be researched in the warehouses of the Göcseji Múzeum in Zalaegerszeg (city museum with county authority) as well as two district museums, that is, the Balatoni Museum in Keszthely and the Thúry György Museum in Nagykanizsa. These three institutions safeguard the documentation of the excavations in the database, too. The digital archive of the documents related to the preventive excavations of the M7-M70 motorways is the property of the database of the Göcseji Museum in Zalaegerszeg, which is the legal successor of the Zala Megyei Múzeumok Igazgatósága (Directorate of the Museums in Zala County). At the same time, the archaeological materials of the M7-M70 motorways belong to the Thúry György Museum as far as the collection area is concerned, so the materials in the cabinet cadastre inventory form a separate collection in this institution.

The dissertation was completed after the exhaustive review of the Late Bronze Age archaeological finds located in the three museums of the county and the documantations related to the finds. On the basis of this work the sites that are substantial concerning information were chosen. After the detailed analysis and multi-aspect presentation of the sites the dissertation relies on them as far as its conclusions are concerned.

The starting point of the dissertation is the data collection in data repositories and professional literature that reflects the current state of the Bronze Age archaeological sites of Zala County. Data collection is based on the sites included in the central registry, the information found in the database of the museums, the topographical data collecting the archaeological sites of 
the Keszthely District released by the Archaeological Topography of Hungary (MRT) in 1966, two monographies that are considered to be basic publications regarding the examined area as well as publications related to the area of the county, which process the archaeological sites of the period. As for the publications, I could base my dissertation on the precious works of László Horváth, the late director of the Thúry György Museum and Róbert Müller, the retired director of the Balatoni Museum.

The group of the most significant sources contains the research projects that are specifically related to the themes of the doctoral dissertation, which were carried out with the help of the ELTE Eötvös Loránd University - Institute of Archaeological Sciences. Zoltán Czajlik took aerial photographs for the purpose of assessing the state of the settlements located at high altitudes in Zala County while Gábor V. Szabó and his team carried out a research with the help of metal detectors at several settlements located at high altitudes from the Bronze Age. The findings of both scientific projects are dealt with in the related chapters of the paper. I also carried out field observations as the archaeologist of the Thúry György Museum in order to specify the natural environment of certain sites and the extension of the site.

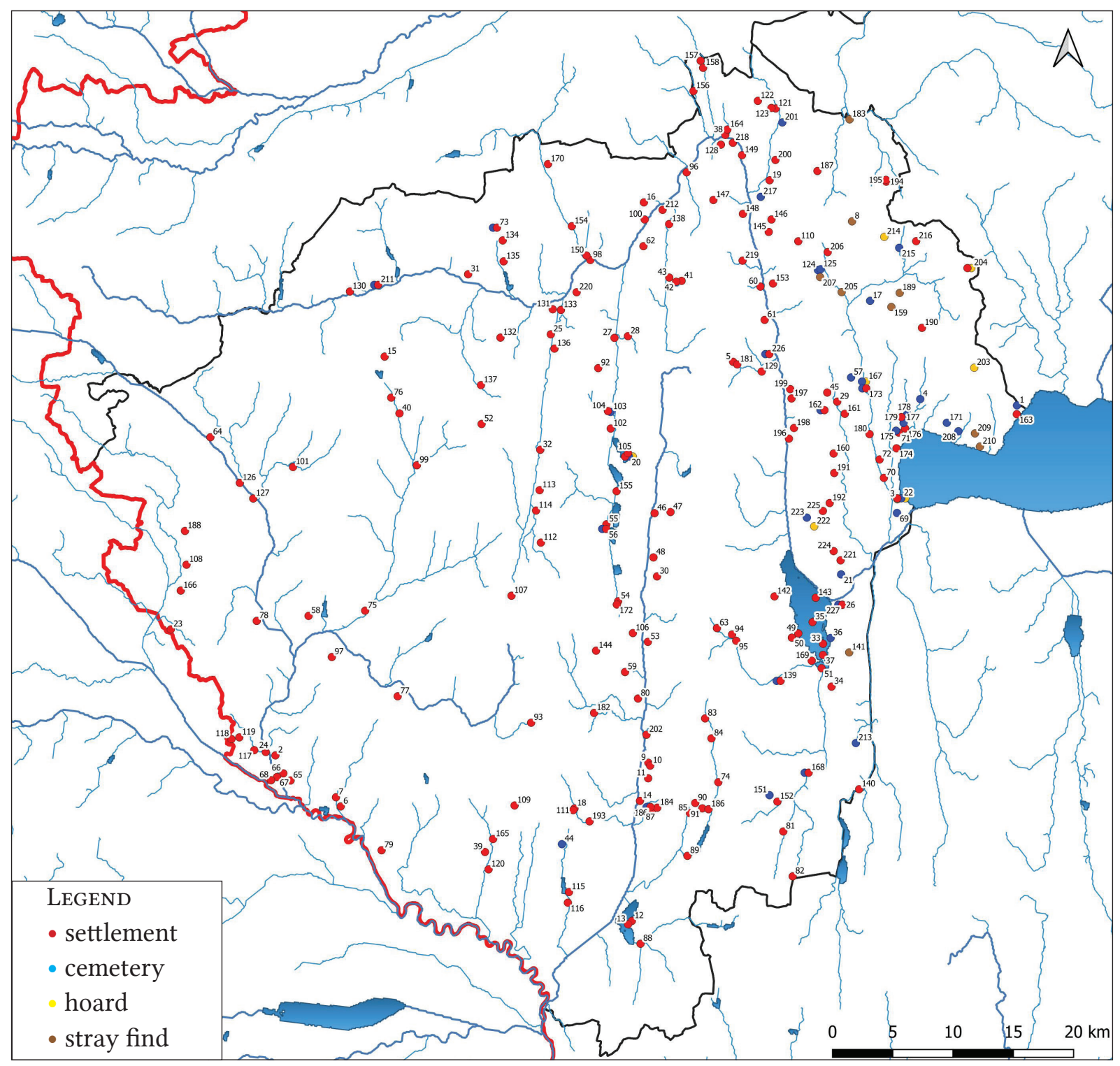

Fig. 1. Late Bronze Age archaeological sites of Zala County. 
The QGIS program is also included in the sources with the help of which the role of settlements at high altitudes in the area of Zala County were examined and the theoretical spheres of influence were defined. The GIS-based illustrations and maps of the dissertation were also generated with the help of the databases that are quantifiable from the researched archaeological data related to the examined area.

The the dissertation is based on the material of the excavation of 6 settlements at high altitudes (Zalaszentiván-Kisfaludi-hegy, Kemendollár-Várdomb, Zalaszántó-Tátika, Rezi-Meleghegy, Várvölgy-Nagyláz-hegy, Oltárc-Márkihegy), 8 settlements on a plain (flatland) (Balatonmagyaród-Hídvégpuszta, Keszthely-Fenékpuszta, Muraszemenye-Aligvári-mező, Tornyiszentmiklós-Nagyszegi-dűlő, Nagykanizsa-Bilkei-dűlő, Nagyrécse-Baráka, Keszthely-Dobogó, Zalacsány-Kőfejtő-dülő), and 5 cemetery parts (Zalakomár-Alsócsalit, Balatonmagyaród-Hídvégpuszta, Galambok-Hársas-erdő, Nagykanizsa-Palin-Szociális Otthon, Zalacséb-Körtvélyes).

As a part of the dissertation the settlement of Muraszemenye-Aligvári-mező and the cemetery of Zalakomár-Alsócsalit were fully processed and analysed. In the case of the other sites groups of objects and articles representing their archaeological material were presented.

\section{Scientific results of the dissertation}

\section{Processig the archaeological finds}

After the review of the finds and their scientific documentation of the examined 19 sites in the chapters that describe sites some representative finds were included in the source statement from each region of the chosen area (Zala County). The archaeological materials are demonstrated in 374 tables and 235 assessment figures in the text. As a part of the dissertation 6 settlements located at a high altitude were presented while 14 objects from Zalaszentiván-Kisfaludi-hegy and 17 objects from Várvölgy-Nagyláz-hegy were introduced and analysed in details. From among the settlements located on a plain, the appendix of the dissertation contains the description of all the Late Bronze Age objects and the finds' types of the Muraszemenye-Aligvári mező while 40 settlement objects are present in drawn tables by means of detailed analysis. The materials of 4 larger pit complexes from the Tornyiszentmiklós-Nagyszegi-dűlő site, determinative ceramic finds from Nagykanizsa-Bilkei dülö and the characteristic ceramic material from Nagyrécse-Baráka-dűlő were analysed and presented in tables with photos and drawings. The settlement history data of the fortified open settlements of Balatonmagyaród-Hídvégpuszta and Keszthely-Fenékpuszta were also summarised. In the paper Keszthely-Dobogó and Zalacsány-Köfejtö-dülő represent the main characteristics of the northern sites of the county, near the upper watercourse of the Zala River. Type tables also summarise the characteristics of the ceramic materials found at certain sites. Altogether 196 urn graves were processed from the region of the Zala and Mura Rivers: 139 from the Zalakomár-Alsócsalit site, 18 from the Nagykanizsa-Palin-Szociális Otthon site, 16 from the Zalacséb-Körtvélyes site, 17 from the Galambok-Hársas-erdő site and 6 from the Hahót-Vadaskert site. The paper mentioned the finds of the 56-grave cemetery in Balatonmagyaród-Hídvégpuszta in some details.

\section{Topograpical, land use and settlement structure analyses}

The findings of the dissertation are those topographical researches that depict the particular sites on a topographical map, placed on an orthophoto and projected on the military map from the period of Joseph II. The topographical position of the certain sites gave answers to the land 
use of the era. The informative ground plans created on the basis of the cumulative ground plans and showing the particular part of the Bronze Age settlement/cemetery served as sources regarding the characteristics of the settlement and cemetery structures. The dissertation examined the role of the settlements of Zala County in the landscape in a separate chapter. It made an attempt to separate the theoretical spheres of influence of the settlements located at high altitudes. The dominant part of the dissertation was made up by the presented visibility and viewshed analyses. These involved the examination of fortified settlements located at high altitudes from the Late Bronze Age in the area of Zala County (Zalaszentiván-Kisfaludi-hegy, Kemendollár-Várdomb, Rezi-Meleg-hegy/Vár, Zalaszántó-Tátika/Vár, Várvölgy-Nagyláz hegy) as well as two other fortified settlements located on a plain (Keszthely-Fenékpuszta and Balatonmagyaród-Hídvégpuszta). In the case of the strongholds located at high altitudes they are based on the fact that due to the location of the settlement the inhabitants of the settlements have the opportunity to observe their surroundings as there is a positive correlation between their altitude and the visible area.

\section{The region of the Zala and Mura Rivers in the Late Bronze Age (late Tumulus and Urnfield period)}

At the moment 260 sites are officially registered from the Late Bronze Age in the area of Zala County. The sites of Zala County from the Bronze Age are located in accordance with the geographical features, in the meridional valleys positioned in the north-south direction, near the water sources, on their high banks. For the time being it seems to be the case that the eastern part of the county was more densely populated in the examined period.

\section{Settlements}

Through the sites presented in the paper two basic groups can be distinguished regarding settlement structure: 1. Settlements with dispersed structure: Among the unearthed sites a typical example is the Nagyrécse-Baráka-dűlő. Here the object groups consisting of round pits and amorphous pit complexes referring to the basic units of the settlement were positioned at a relatively large area, and there was a 50-250-meter distance between them. 2. Settlements with a closed structure or intensive settlements: as the result of excavations covering large surfaces several sites can be placed into this category: Muraszemenye-Aligvári-mező, Tornyiszentmiklós-Nagyszegi-dűlő, Várvölgy-Nagyláz hegy. For the establishment of open villages on plains the territory delimited by the Mura Valley - Lower Valley of Zala River - Lake Balaton (Keszthely Basin) provides an advantageous opportunity. On the basis of the uniform geographical environment and the settlements that existed at almost the same time, this region can be treated as a microregion. The Nagykanizsa-Muraszemenye-Tornyiszentmiklós route has been an important connection towards the Adriatic Sea since the Neolithic period until the present date. Two large sites located on the left plain of the Mura River can be classified as classic open settlements: Muraszemenye-Aligvári-mező and Tornyiszentmiklós-Nagyszegi-dülő. Due to the current spatial extent and regional nature of the researches the settlements from the Late Bronze Age located in the territory of the Zala and the Mura provide information on settlement structure primarily in connection with the BD-HaA1 period. As a result of the dissertation on the plain on the left bank of the Mura River, in the area between the Mura River and the Kis-Balaton (Tornyiszentmiklós-Muraszemenye-Nagykanizsa-Nagyrécse- 
Balatonmagyaród) it was possible to distinguish a well-defined group of sites of the late Tumulus and early Urnfield period that had connections in the Mura, Dráva and Száva regions in the BD-HaA1 period.

The network and hierarchy of the settlements in the BD-HaA1 era were defined by the smaller settlements located near smaller watercourses, which had fewer finds (Nagyrécse-Baráka) on the one hand and by the larger settlements having more finds, located along the outstandingly important, north-south positioned communication channel (upper watercourse of the ZalaMura region) as well as the east-west positioned communication channel (Balaton-Nagykanizsa-Mura region): Muraszemenye-Aligvári-mező, Tornyiszentmiklós-Nagyszegi-dűlő, Nagykanizsa-Inkey-kápolna, Nagykanizsa-Bilkei-dűlő, Balatonmagyaród-Hídvégpuszta on the other hand. In the case of the sites of the BD-HaA1 era we can mention primarily economic hierarchy. In the case of the larger settlements near determinant transport geographical junctions there are no data for the existence of a tribal centre of power in the examined region and period.

In the area of Zala County six fortified settlements located at high altitudes can be found, which were used in the Late Bronze Age period. These were established on the plateau of the hills and made use of the natural protection, but they were artificially fortified intensively inhabited settlements.

Compared to other regions of the Transdanubia, the settlements located at high altitudes in the region of the Zala and the Mura Rivers form a separate microregion. The six settlements located at high altitudes, among which five were definitely fortified, had a dominant settlement position in the landscape and in connection with the plain area surrounding it. Research is lucky because we have most information on the biggest fortified Bronze Age settlement (160 ha) of the Transdanubia. This settlement located at a high altitude has close connections with the Velem-Szent Vid-hegy regarding its rich archaeological materials. On the basis of the 14 bronze treasures and two golden finds as well as the dispersed bronze finds from the surroundings of the site it was the economic-social-religious centre of the region. Concerning their functions, the fortified settlements located at high altitudes are different. The VárvölgyNagyláz-hegy is the biggest and it may have been a centre with resident population, industrial bronze casting and representative treasures. The settlement of Várvölgy may have controlled the foreground of Lake Balaton as it was an important commercial and transportation junction. The strongholds of Rezi-Vár and Tátika-Vár must have been built during the Late Bronze Age. We do not have any information about the inner structure of the settlements and the intensity of people settling down. The fortified settlement at Zalaszentiván-Kisfaludi-hegy over the Zala River may have been a dominant settlement that had a resident population on the basis of the excavations. The observed houses hollowed into the ground, the pole holes and ovens prove this. Determinant bronze finds were unearthed from the site during the research carried out by means of metal detectors, too. In addition, two moulding patterns carved from sandstone prove the craftsman activity on the spot. The north-west and west-east positioned routes along the Zala River might have been controlled also by Kemendollár-Várdomb that probably did not have a resident population. The size of Oltárc-Márkihegy and the bronze treasure unearthed at the foot of the hill confirms the central role of the site in the region. No other central fortified settlement located at a high altitude is known from the period until the settlement of Ormož along the Dráva River. Due to its geographical position Oltárc might 
have controlled a more importent tribal border. This assumption will need confirmation in the future. However, the settlements located on plain areas of the HaA1 period and their strong connections towards south-west and south-east seem to support it.

On the basis of the finds reviewed in the paper and the analyses carried out it was established that there was a significant difference in the quality of the finds in the BD-HaA1 period. The archaeological materials of the Mura microregion (Muraszemenye-Aligvári-mező, Tornyiszentmiklós-Nagyszegi-dűlő, Nagykanizsa-Inkey-kápolna, Nagykanizsa-Bilkei-dűlő, Nagyrécse-Baráka-dűlő, Balatonmagyaród-Hídvégpuszta) refers to a connection maintained with the southern and south-eastern regions. Regarding the settlements the connection towards the northern, north-eastern Bakony group can be demonstrated to a smaller extent but is its dominant. The design, form and relationship network of the finds unearthed at the sites near the upper watercourse of the Zala River, in the surroundings of Keszthely and in the area of the upper Zala Valley are different. Here the connection towards north and north-east is more direct.

In the $\mathrm{HaA} 2-\mathrm{HaB}$ period the number of the sites in the area of Zala County decreases, too. Settlement concentration is evidently typical of the period. The era is the heyday of the fortified settlements located at high altitudes while the number of the open settlements located on plain areas drastically decreases. On the basis of the collaction of the settlement data I assume that in the future we must look for the open settlements located on a plain area of the period around the fortified settlements but not in their immediate surroundings.

\section{The results of the visibility analyses}

Based on the used visibility analysis it became visible that there are no settlements in the plain areas in the immediate surroundings of the settlements located at a high altitude. The explanation of the reason for the lack of them may be one direction of the research. It can also be considered an important finding that the visibility between the settlements located at high altitudes was guaranteed. A determinant visual control is outlined in connection with the examined area. The statement according to which nobody could have a view over the Zalaszántó-Tátika site as its altitude is the highest also belongs to the results of the visibility analysis. However, it was possible to see the height, although not from above but from a position that was a bit lower - from Rezi and Várvölgy, too (e.g. the smoke from the fire may have been clearly seen). From the height of Tátika it was possible to see Rezi and Várvölgy and even regarding the distant Oltárc-Márkihegy there was a visual control. In spite of its geographical separation, Oltárc-Márkihegy may have had visual control over the Kemendollár-Várdomb and the abovementioned Zalaszántó-Tátika sites. On the basis of the visibility analysis it can be conclusively demonstrated that the population of the settlement in Oltárc may have been able to control the route of the county along the Principális canal, in north-south direction. From the Zalaszentiván-Kisfaludi-hegy site the flood plain of the Zala River and the surroundings of its tributary to the north can be seen but no settlement is visible. However, from the Kemendollár-Várdomb nearby it is possible to see a relatively large area to the north. I suppose that concerning their functions the two settlements might have complemented each other. We do not have any data about an intensive residential area for the time being at the settlement of Kemendollár and its territory is relatively small. From the two settlements it was possible to control the upper part of the Zala River positioned in east-west direction, which 
had strategic importance. Based on the generated maps it is clearly shown that the western part of the county is outside the range of visibility. There are no settlements located at high altitudes and the number of the settlements located in plain areas is also smaller. On the whole, the strongholds kept the complete examined area under visual control - excluding the western third of the county.

\section{Burials}

When choosing the location of the cemetery the proximity of water was the primary criterion. All the unearthed cemetery parts were located on a hill delimited by the intersection of watercourses. The streams and smaller watercourses are dominant landscape features of the cemeteries. In the cemeteries the old and new burials were located near each other within the same group. The cemetery and the certain grave groups were used for both sexes - that is, men, women and children were buried everywhere and there was no separate segment in the cemeteries of Zala county from this aspect, either. The fundamental element of the burial rite, the cremation of the deceased was not influenced by their sex and age. Two relatively large cemetery parts in Zalakmár-Alsócsalit and Balatonmagyaród-Hídvégpuszta provided opportunity for highlighting the general characteristics. Cremation is supposed to have been carried out in the cemeteries, too. We can locate them in the larger empty areas among the graves and certain grave groups.

The customs of giving a burial deposit has characteristics, too. In the $\mathrm{BD}$ and $\mathrm{BD} / \mathrm{HaA} 1$ period not many filigree wire jewels survived due to cremation but based on the cemetery of Zalakomár-Alsócsalit they were the characteristic grave goods of graves for burying women. Certain pot types may have belonged to a specific group, too. The tubular-base bowl may have been an example of this as it was placed into several graves in Zala County and might have been the burial deposit of the graves of rich women. I guess the "solitary" brooches found in the cremation pit graves, also on the basis of the graves in Zalakomár and Galambok containing weapons, is an attribute linked to men. The graves containing weapons can be obviously likned to men but these are relatively rare. However, in the cemeteries of Zalakomár-Alsócsalit and Galambok-Hársas-erdő a grave group with a sword was found.

Based on the determinant metal finds and graves with weapons the archaeological materials of Zala County can be linked to the tumuli of the Bakony group. However, the form of the ceramic finds, including the tubular-based bowl, as well as the certain urn types connect the burials of the region to the Virovitica cultural group. Regarding the burial rite, on the basis of the burials into simple, round or oval graves and the finds of the graves the burials of Zala County can be related to the finds of the cemeteries unearthed in the area of Austria from the same era in Horn and Baierdorf as well as with the burials of the Čaka group and Velatice phase in the area of Slovakia. The relation to the rich finds of the Čaka tumuli and the Bakony region is a clear evidence for the idea that the cultural influences were streaming from the north to the south in the $\mathrm{BD}$ and $\mathrm{BD} / \mathrm{HaA} 1$ periods. In the case of the graves from the HaA1HaA2 periodit is possible to demonstrate the cultural interactions of the Mura-Dráva-Száva region from the south to the north, too. As the imprint of the interregional relationships it is also possible to trace the connections with Italian (razor handle fragments) and East-Bavarian (bronze needle) territories, too. The rich bronzesmithing and the golden articles are the evidence that the region participated in the long-distance trade. 
Based on the incomplete data it seems to be the case that the settlements and the cemeteries located near them may have been of about the same age and their establishment may have served the needs of the settlement's community. In order to refine the questions further examinations are necessary.

\section{Depot finds}

More than half of the bronze treasures unearthed in the area of Zala County can be related to the settlements located at high altitudes. The depots in Várvölgy and Zalaszentiván were found in the area of the settlement while the find in Oltárc was unearthed at the foot of the hill so it can be classified as a solitary depot. Based on the settlement structure analyses the former deposit zones were assigned near the entrance of the settlement in Zalaszentiván while at the Várvölgy-Nagyláz hegy site the zones were defined to the north-west direction from the assumed entrance of the settlement by the road towards the Méházi Lake.

Processing the sites from the Late Bronze Age (late Tumulus and Urnfield period) known in the regions of the Zala and Mura Rivers as well as their finds, and their multi-aspect analysis made an attempt to provide a comprehensive picture of the examined region, according to the objectives of the dissertation. The dissertation intended to position the materials in Zala County to the level where, based on the sources, they may be the starting point of further regional and interregional researches.

\section{The publications released in the topic of the dissertation}

SzÁRAZ, Cs. 2000: Központok az őskorban. In: Vándor, L. (szerk.): Központok a Zala mentén. A Göcseji Múzeum állandó kiállítása. Katalógus. Zalaegerszeg, 7-22.

SzÁRAz, Cs. 2002: Zalaszentiván-Kisfaludi hill. The prehistoric material of the hillfort. In: BÁNFFy, E. (ed.): Prehistoric Studies in memoriam Ida Bognár-Kutzián. Antaeus 25. Budapest, 513-546.

SzÁRAz, Cs. 2006: Késő bronzkori fémleltek Muraszemenye-Aligvári-mező lelőhelyről (Late Bronze Age metal objects from Muraszemenye-Aligvári-mező). Zalai Múzeum 15, 171-187.

SzÁRAz, Cs. 2008: Késő bronzkori urnasírok Galambok-Hársas-erdő lelőhelyen (Late Bronze Age urn graves at Galambok-Hársas-erdő). Zalai Múzeum 17, 65-78.

SzÁRAZ, Cs. 2010: Késő vaskori áldozati gödrök Zalaszentiván-Kisfaludi-hegy lelőhelyen. Zalai Múzeum 19, 117-138.

SzÁRAz, Cs. 2017a: A Hahót-Vadaskert-dűlő lelőhelyen előkerült késő bronzkori temetőrészlet bemutatása (A presentation of the cemetery part found at Hahót-Vadaskert-dủlő archaeological site). Zalai Múzeum 23, 53-72.

SzÁraz, Cs. 2017b: Prehistoric Center above the Zala River. The Results of Recent Research at Zalaszentiván-Kisfaludi Hill. Hungarian Archaeology E-Journal, 2017 Spring, 1-7. (http://files.archaeolingua.hu/2017TA/sz\%e1raz_eng_17ta.pdf) last access: 10. 02. 2021.

SzÁrAz, Cs. 2017c: Late Bronze Age Sites in Zala County (Southwestern Hungary). In: Kulcsár, G.V. Szabó, G.-Kiss, V.-VÁczi, G. (eds): State of the Hungarian Bronze Age Research. Proceedings of the conference held between 17th and 18th of December 2014. Ösrégészeti Tanulmányok/Prehistoric Studies 2. Budapest, 51-84. 